\title{
Experimental Production of Composite Fiber for Additive Production Technology
}

\author{
Martin Pollák ${ }^{1}$, Marek Kočiško ${ }^{1}$, Anna Bašistová ${ }^{1}$ \\ ${ }^{1}$ Technical University of Košice, Faculty of Manufacturing Technologies with a seat in Prešov, \\ Bayerova 1, 08001 Prešov, Slovak Republic
}

\begin{abstract}
In recent years, additive production technology has spread to almost all manufacturing areas. In most cases, a fiber is used as an input material in the 3D printing process, the required properties of which are mainly its strength and durability. With the ongoing development of the 3D printing techniques, the need to develop fibers that do not pose a burden to the environment comes to the fore. This paper points out the possibilities of producing fibers intended for additive production. The paper describes the fiber production on FilaFab PRO EX350 device used for producing fibers for the 3D printing technology. The aim of the paper is to describe the production of fibers and to compare commonly available fibers with the experimentally made ones. To run the tests, a clear fiber and a composite fiber with carbon powder filler were produced. The mechanical properties achieved by these experimentally produced fibers were compared in tensile tests with commonly available fibers purchased from sellers of 3D printing materials.
\end{abstract}

Keywords - Additive production, Composite material, Fiber production, FilaFab PRO EX350, PLA material Ingeo 2003D.

DOI: $10.18421 /$ TEM102-57

https://doi.org/10.18421/TEM102-57

Corresponding author: Martin Pollák, Technical University of Košice, Faculty of Manufacturing Technologies with a seat in Prešov, Slovak Republic Email: martin.pollak@tuke.sk

Received: 17 February 2021.

Revised: 24 April 2021.

Accepted: 03 May 2021.

Published: 27 May 2021.

(cc)BY-NC-ND (C) 2021 Martin Pollák, Marek Kočiško \& Anna Bašistová; published by UIKTEN. This work is licensed under the Creative Commons AttributionNonCommercial-NoDerivs 4.0 License.

The article is published with Open Access at www.temjournal.com

\section{Introduction}

Nowadays, we are surrounded by various products made of plastic materials, whether at home or at work [1],[2]. Although the goal of various institutions is currently to reduce the amount of plastics on Earth, each of us should be involved in reducing the use of plastics. In our rapidly evolving times, new products manufacturing needs to observe the principles of the lowest possible product development lead time and the lowest possible production costs [3], [4], [5]. In this respect, the 3D printing technology, which is the subject of a number of studies by the authors such as Gibson et al. [6] and also Zhang et al. [7], takes the center stage. Due to the need to reduce the plastics production, it is necessary to consider replacing the material used in the 3D printing process with its most environmentally friendly variant. In their paper, the authors Babu et al. [8] dealt with the development of large-scale products made from several types of materials through interconnecting robotics with the 3D printing technology, in which they investigated the solidification properties of the materials used for production and their resulting structure. At present, despite the rapid development of new materials for additive production, the PLA material (polylactic acid) is still the most widely used, and it is considered an ecological material that, unlike other materials, is obtained from renewable and natural raw materials. Polylactic acid belongs to the family of natural materials. Its advantage is that it is not derived from fossil fuels, such as ABS (acrylonitrile butadiene styrene), which is produced from crude oil. The paper by Cali et al. [9] describes and analyses the production of five new thermoplastics (organic bioplastics made from PLA) filler materials. The authors Kuznetsov et al. [10] conducted a similar research documented in their respective paper, investigating the effect of hardware setup of multiple $3 \mathrm{D}$ printers from different commercial manufacturers on the same selected parameters of the $3 \mathrm{D}$ printing process of the same fibers (input material) from which they produced test specimens that were subsequently subjected to testing. The ever- 
increasing interest in these new composite materials, reinforced with organic by-products, is due to the growing need to reduce production management costs and, last but not least, their low impact (in terms of safety) on the environment. This stems from researching new materials, thanks to which we can replace commonly used materials, and thus prevent the production of components and parts from hardto-decompose plastics. These issues, and other future trends, are addressed also by Li et al. [11].

The paper describes the process of fiber production as an input material for 3D printing technology, using the FilaFab PRO EX350 (extruder). The fibers produced can be used for $3 \mathrm{D}$ printing of various components in various areas. The study described in the paper aims to contribute, at least in part, to the reduction of adverse effects on the environment through the production of own fibers, particularly by using environmentally friendly materials.

\section{The Preparation and Course of the Experiment}

For fiber formation, a granular transparent bio geopolymer PLA material with a size of $5-7 \mathrm{~mm}$ under the brand name Ingeo 2003D from the manufacturer Nature Works was chosen as the 3D printing building material. Choosing the PLA (polylactic acid) building material stemmed from its suitability for the FilaFab PRO EX350 and from material's the non-toxicity. The Ingeo 2003D is characterized by high impact resistance, easy processability, good adhesion to the worktop and high 3D printing accuracy. Unlike commonly used commercial materials, PLA is one of the materials with the least impact on the environment. This type of material was used specifically for that reason. The condition for fiber production was that the fiber has to maintain its diameter of $1,75 \mathrm{~mm} \pm 0,05 \mathrm{~mm}$ along its entire length, designated to be used in a $3 \mathrm{D}$ printer Creality Ender, printing the test specimens from individual materials [12], [13].

The production process consisted of gradually adding the selected PLA material to the hopper of an extruder for 3D printing fiber production without the filler in case of the clear fiber production and with a carbon powder filler of a specified formula for the second fiber type. Under the set pressure and temperature, the granulated PLA material and the filler blend into a homogeneous mass, which is then extruded through an extruder nozzle of the desired fiber size. The produced fiber was cooled at the outlet by an external ventilation device and wound on a spool by a winder. When the fiber was produced, it was visually inspected and measured for its quality and accuracy for its subsequent use in the 3D printing process.

In the production of new fibers, care has to be taken to ensure that the fibers formed meet mechanical properties such as, e.g. strength and durability [14], [15], [16]. The fibers processed into the test specimens were subjected to tensile tests. The main task was the production of clear fibers, as well as fibers with the addition of filler in the form of carbon powder using the FilaFab PRO EX350 and comparing them with commercially available materials for $3 \mathrm{D}$ printing. Table 1 shows the combinations of materials and filler used in the experimental formation of the clear fiber and the composite fiber with the carbon powder filler.

Table 1. Material used in the fiber production

\begin{tabular}{|c|c|c|}
\hline Fiber type & Material & Filler \\
\hline Clear PLA fiber & Ingeo 2003D & $/$ \\
\hline Carbon fiber & Ingeo 2003D & Carbon powder \\
\hline
\end{tabular}

\subsection{Clear Fiber Production Process from Ingeo 2003D}

The first experimental fiber production focused on the production of fiber from the selected material without the use of filler. The granular Ingeo 2003D was placed in the hopper of a FilaFab Pro EX350 fiber machine. Under the temperature and pressure, a homogeneous mixture was formed, which was subsequently extruded through the extruder nozzle of the desired fiber size. The formed fiber was cooled by an external ventilator and wound on a spool by a winder.

\subsection{Process of Fiber Production from Ingeo 2003D with a Carbon Powder Filler}

Further production focused on creating fiber with $10 \%$ carbon powder filler content. At the formulated ratio and constant diameter, the fiber extruded through the extruder nozzle was of a deep black color. The fiber extrusion speed was the same as that of the pure Ingeo 2003D fiber extrusion, and no visible defects occurred during the manufacturing process. The advantage of carbon powder is its demonstrable strength and adhesion of the layer with very low deformation in the $3 \mathrm{D}$ printing process. 


\section{Testing and Evaluation of Materials used in Specimen Production}

To test the fibers, 40 test specimens were made of different materials, which were then tested in a tensile test and the results were mutually compared. Ten specimens were generated from each experimental material. Of the total number of specimens, 20 test specimens were from a set of fibers produced by us using the FilaFab Pro EX350 and 20 specimens were formed from fibers purchased from commercial manufacturers. The test specimens were prepared according to the STN 527 standard. Table 2 shows combinations of experimental test specimens.

Table 2. Types and designation of test specimens

\begin{tabular}{|c|c|c|}
\hline Name & Type of material & Manufacturer \\
\hline $\mathbf{1 - 1 0} / \mathbf{A}$ & Clear PLA & Experimental material \\
\hline $\mathbf{1 - 1 0} / \mathbf{B}$ & Clear PLA fiber & Commercial manufacturer \\
\hline $\mathbf{1 - 1 0} / \mathbf{C}$ & Carbon fiber & Commercial manufacturer \\
\hline $\mathbf{1 - 1 0} / \mathbf{D}$ & PLA + Carbon powder & Experimental material \\
\hline
\end{tabular}

Tensile tests were conducted on an Istron 5982$100 \mathrm{kN}$ shredder. During the test, the values of the load acting on the test specimen were recorded. The test was done at a constant speed of $20 \mathrm{~mm} / \mathrm{min}$. The results of tensile tests are represented by a graph of dependence values between the stress and deformation properties of the test specimen. A tensile chart was used to evaluate the tests, describing the resulting elongation of the test specimen as a function of the applied load force.

\subsection{Group A test specimens - filler-free experimental material PLA Ingeo 2003D}

Table 3 shows the results of tests performed on 10 test specimens of group A from experimental fillerfree PLA material Ingeo 2003D.

Table 3. Tensile test results - group A test specimens

\begin{tabular}{|c|c|c|c|c|c|c|c|}
\hline & $\begin{array}{c}\text { Maximal } \\
\text { force } \\
\text { [N] }\end{array}$ & $\begin{array}{c}\text { Tensile } \\
\text { stress at } \\
\text { max. force } \\
\text { [MPa] }\end{array}$ & $\begin{array}{c}\text { Extension at } \\
\text { max. force } \\
\text { [mm] }\end{array}$ & $\begin{array}{c}\text { Force at yield } \\
\text { strength } \\
\text { (Shift 0,2 \%) } \\
\text { [N] }\end{array}$ & $\begin{array}{c}\text { Tensile stress at the } \\
\text { yield strength } \\
\text { (Shift 0,2 \%) [MPa] }\end{array}$ & $\begin{array}{c}\text { Tensile } \\
\text { deformation at } \\
\text { failure [\%] }\end{array}$ & $\begin{array}{c}\text { Speed } \\
\text { [mm/min] }\end{array}$ \\
\hline $\mathbf{1}$ & 648,65 & 76,31 & 1,62 & 635,77 & 74,80 & 4,43 & 20 \\
\hline $\mathbf{2}$ & 462,87 & 54,45 & 1,62 & 415,39 & 48,87 & 3,58 & 20 \\
\hline $\mathbf{3}$ & 883,18 & 103,90 & 1,96 & 821,54 & 96,65 & 5,17 & 20 \\
\hline $\mathbf{4}$ & 794,53 & 93,47 & 1,36 & 778,92 & 91,64 & 2,73 & 20 \\
\hline $\mathbf{5}$ & 508,66 & 59,84 & 1,18 & 474,74 & 55,85 & 2,26 & 20 \\
\hline $\mathbf{6}$ & 893,03 & 105,06 & 1,58 & 882,10 & 103,78 & 2,97 & 20 \\
\hline $\mathbf{7}$ & 394,61 & 46,43 & 1,64 & 361,15 & 42,49 & 3,02 & 20 \\
\hline $\mathbf{8}$ & 864,25 & 101,68 & 2,20 & 801,57 & 94,30 & 4,20 & 20 \\
\hline $\mathbf{9}$ & 887,26 & 104,38 & 1,88 & 826,46 & 97,23 & 3,35 & 20 \\
\hline $\mathbf{1 0}$ & 494,90 & 58,22 & 2,20 & 450,05 & 52,95 & 4,75 & 20 \\
\hline
\end{tabular}

Figure 1 shows a graphical dependence of the tensile stress on the proportional deformation for the A test group of specimens and Figure 2 shows a photograph of the test specimens torn in the tensile test.

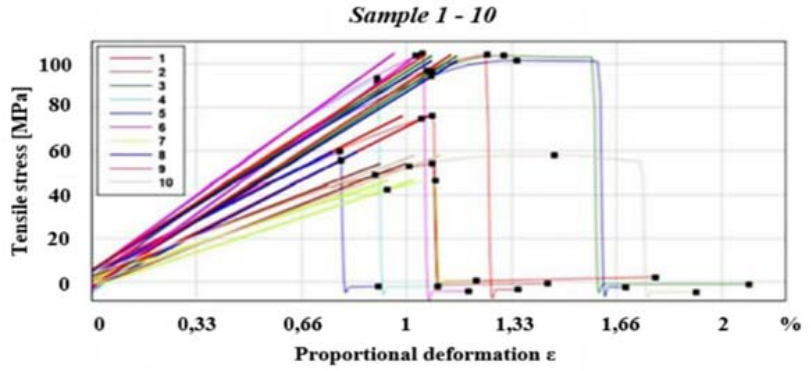

Figure 1. Graphical dependence of tensile stress on proportional deformation - specimens A

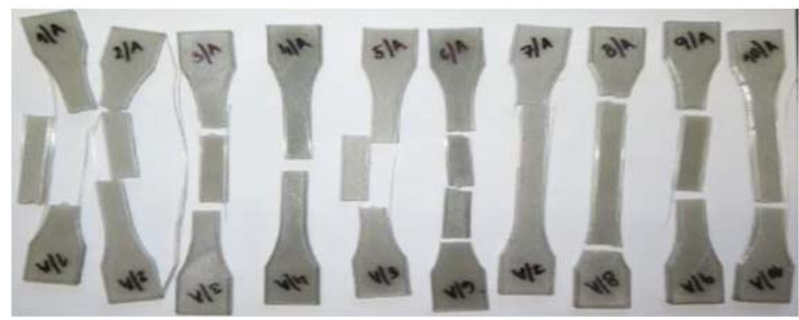

Figure 2. Torn A group test specimens

\subsection{B Test Specimens - Filler-Free PLA Material (commercial material)}

Further tests were done on 10 test specimens of a purchased filler-free PLA material. The results of the tensile test on the group of tested specimens B are shown in Table 4. 
Table 4. Tensile test results - B group test specimens

\begin{tabular}{|c|c|c|c|c|c|c|c|}
\hline & $\begin{array}{c}\text { Maximal } \\
\text { force } \\
{[\mathrm{N}]}\end{array}$ & $\begin{array}{c}\text { Tensile } \\
\text { stress at } \\
\text { max. force } \\
\text { [MPa] } \\
\end{array}$ & $\begin{array}{l}\text { Extension } \\
\text { at max. } \\
\text { force }[\mathrm{mm}]\end{array}$ & $\begin{array}{c}\text { Force at yield } \\
\text { strength } \\
\text { (Shift } 0,2 \%) \\
{[\mathrm{N}]}\end{array}$ & $\begin{array}{c}\text { Tensile stress at } \\
\text { the yield strength } \\
\text { (Shift } 0,2 \%) \\
{[\mathrm{MPa}]}\end{array}$ & $\begin{array}{c}\text { Tensile } \\
\text { deformation } \\
\text { at failure } \\
{[\%]}\end{array}$ & $\begin{array}{c}\text { Speed } \\
{[\mathrm{mm} / \mathrm{min}]}\end{array}$ \\
\hline 1 & 1866,03 & 219,53 & 2,35 & 1683,16 & 198,02 & 4,40 & 20 \\
\hline 2 & 1912,85 & 225,04 & 2,39 & 1729,32 & 203,45 & 4,46 & 20 \\
\hline 3 & 1166,18 & 137,20 & 1,08 & 1080,53 & 127,12 & 1,79 & 20 \\
\hline 4 & 1895,01 & 222,94 & 2,27 & 1741,96 & 204,94 & 4,20 & 20 \\
\hline 5 & 1934,88 & 227,63 & 2,24 & 1792,80 & 210,92 & 4,00 & 20 \\
\hline 6 & 2494,69 & 293,49 & 2,36 & 2343,21 & 275,67 & 6,00 & 20 \\
\hline 7 & 2188,16 & 257,43 & 2,42 & 1978,17 & 232,73 & 6,93 & 20 \\
\hline 8 & 2013,12 & 236,84 & 2,34 & 1825,50 & 214,77 & 4,79 & 20 \\
\hline 9 & 1622,31 & 190,86 & 2,20 & 1461,23 & 171,91 & 3,93 & 20 \\
\hline 10 & 1805,23 & 212,38 & 2,28 & 1614,49 & 189,94 & 4,02 & 20 \\
\hline
\end{tabular}

Figure 3 shows a graphical dependence of the tensile stress on the proportional deformation for the B group of test specimens, and Figure 4 shows a photograph of the test specimens torn in the tensile test.

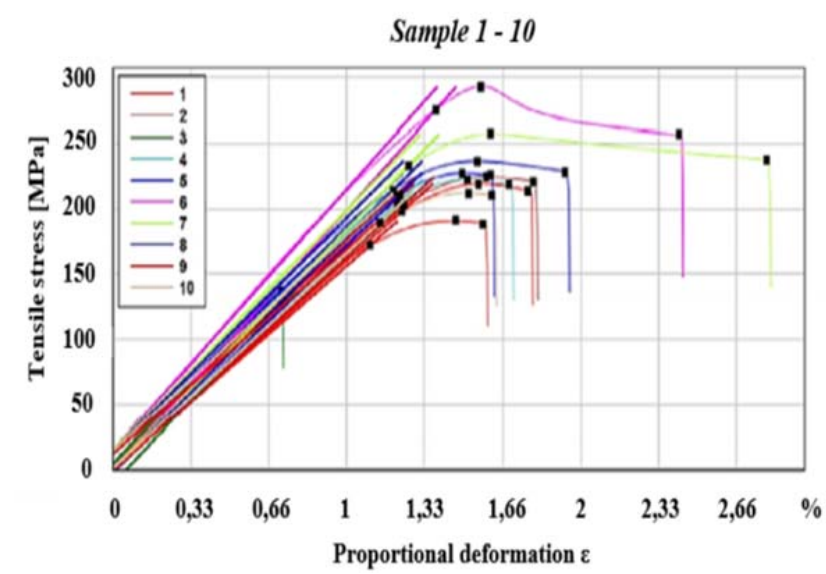

Figure 3. Graphical dependence of tensile stress on proportional deformation - specimens $B$

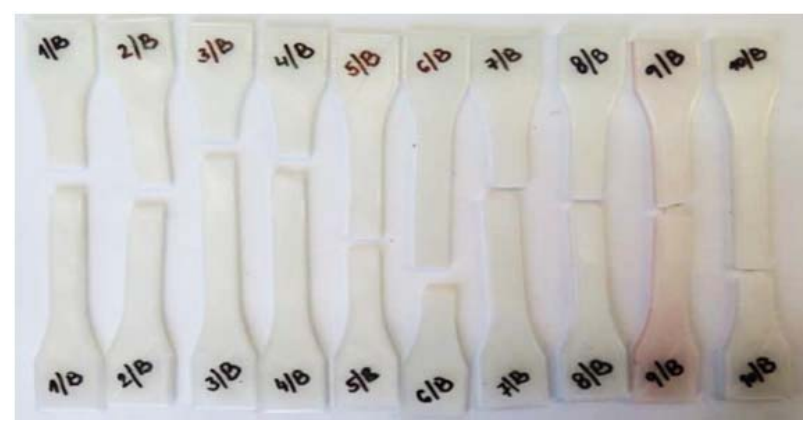

Figure 4. Torn B group test specimens

\subsection{Group C Test Specimens - PLA Material with Carbon Powder Admixture (commercial material)}

In this test, again 10 test specimens were tested but these were made of PLA material with carbon powder filler (commercial material). The results of the tensile test of the $\mathrm{C}$ group of test specimens are shown in Table 5.

Table 5. Tensile test results - group C test specimens

\begin{tabular}{|c|c|c|c|c|c|c|c|}
\hline & $\begin{array}{c}\text { Maximal } \\
\text { force } \\
{[\mathrm{N}]}\end{array}$ & $\begin{array}{c}\text { Tensile } \\
\text { stress at } \\
\text { max. force } \\
\text { [MPa] }\end{array}$ & $\begin{array}{c}\text { Extension } \\
\text { at max. } \\
\text { force } \\
\text { [mm] }\end{array}$ & $\begin{array}{l}\text { Force at yield } \\
\text { strength } \\
\text { (Shift } 0,2 \% \text { ) } \\
{[\mathrm{N}]}\end{array}$ & $\begin{array}{c}\text { Tensile stress at } \\
\text { the yield strength } \\
\text { (Shift } 0,2 \% \text { ) } \\
\text { [MPa] }\end{array}$ & $\begin{array}{c}\text { Tensile } \\
\text { deformation } \\
\text { at failure } \\
{[\%]}\end{array}$ & $\begin{array}{c}\text { Speed } \\
{[\mathrm{mm} / \mathrm{min}]}\end{array}$ \\
\hline 1 & 1579,69 & 185,85 & 2,17 & 1444,84 & 169,98 & 4,47 & 20 \\
\hline 2 & 1845,11 & 217,07 & 2,14 & 1698,46 & 199,82 & 3,85 & 20 \\
\hline 3 & 1464,86 & 172,34 & 2,10 & 1356,51 & 159,59 & 4,32 & 20 \\
\hline 4 & 1831,65 & 215,49 & 2,29 & 1656,52 & 194,88 & 5,28 & 20 \\
\hline 5 & 1003,35 & 118,04 & 2,69 & 879,05 & 103,42 & 4,61 & 20 \\
\hline 6 & 1116,80 & 131,39 & 1,95 & 1014,91 & 119,40 & 3,34 & 20 \\
\hline 7 & 921,38 & 108,40 & 1,77 & 838,90 & 98,69 & 3,91 & 20 \\
\hline 8 & 1475,07 & 173,54 & 2,13 & 1346,68 & 158,43 & 3,82 & 20 \\
\hline 9 & 815,89 & 95,99 & 1,68 & 751,18 & 88,37 & 3,55 & 20 \\
\hline 10 & 1442,98 & 169,76 & 2,11 & 1304,30 & 153,45 & 3,94 & 20 \\
\hline
\end{tabular}


Figure 5 shows a graphical dependence of the tensile stress on the proportional deformation for the $\mathrm{C}$ group of test specimens, and Figure 6 shows a photograph of the test specimens torn in the tensile test.

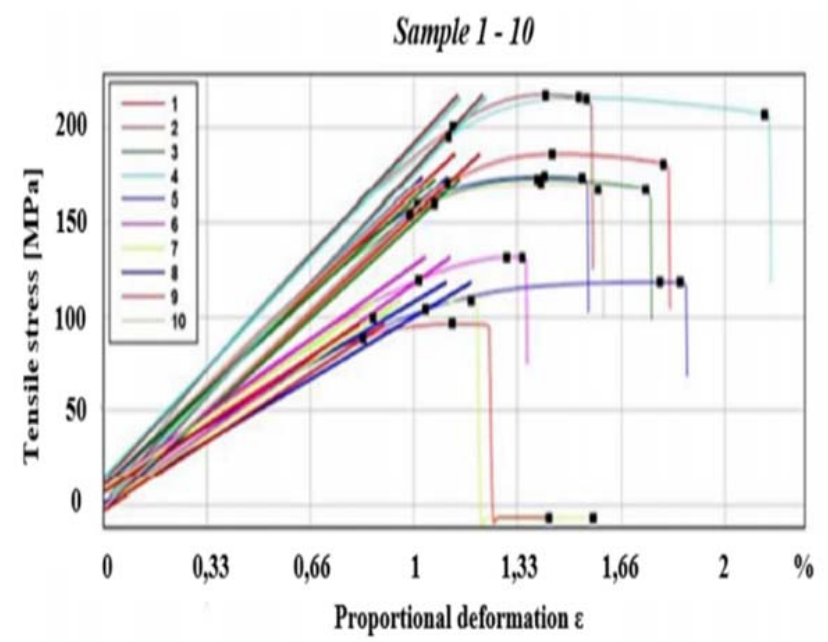

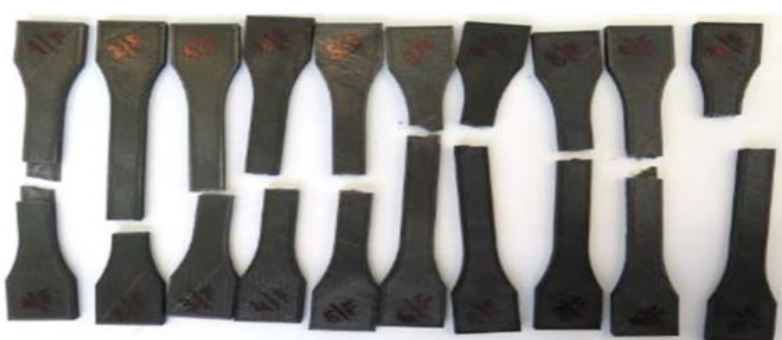

Figure 6. Torn C group test specimens

\subsection{Group D Test Specimens - PLA Material with Carbon Powder Admixture (experimental material)}

For the sake of comparison, 10 test specimens were made of the PLA material mixed with the experimental carbon powder material produced in the laboratory extruder. The results of the tensile test from the experimentally made fiber of group D test specimens are shown in Table 6.

Figure 5. Graphical dependence of tensile stress on proportional deformation - specimens $C$

Table 6. Tensile test results - group D test specimens

\begin{tabular}{|c|c|c|c|c|c|c|c|}
\hline & $\begin{array}{c}\text { Maximal } \\
\text { force } \\
\text { [N] }\end{array}$ & $\begin{array}{c}\text { Tensile } \\
\text { stress at } \\
\text { max. force } \\
\text { [MPa] }\end{array}$ & $\begin{array}{c}\text { Extension } \\
\text { at max. } \\
\text { force } \\
\text { [mm] }\end{array}$ & $\begin{array}{c}\text { Force at yield } \\
\text { strength } \\
\text { (Shift 0,2 \%) } \\
{[\mathbf{N}]}\end{array}$ & $\begin{array}{c}\text { Tensile stress at } \\
\text { the yield strength } \\
\text { (Shift 0,2 \%) } \\
{[\mathbf{M P a}]}\end{array}$ & $\begin{array}{c}\text { Tensile } \\
\text { deformation } \\
\text { at failure } \\
{[\mathbf{\%}]}\end{array}$ & $\begin{array}{c}\text { Speed } \\
\text { [mm/min] }\end{array}$ \\
\hline $\mathbf{1}$ & 1327,35 & 156,16 & 1,92 & 1167,93 & 137,40 & 3,50 & 20 \\
\hline $\mathbf{2}$ & 496,62 & 58,43 & 0,86 & 489,47 & 57,59 & 2,47 & 20 \\
\hline $\mathbf{3}$ & 1348,83 & 158,69 & 1,89 & 1194,40 & 140,42 & 3,30 & 20 \\
\hline $\mathbf{4}$ & 1275,93 & 150,11 & 1,88 & 1132,00 & 133,18 & 3,25 & 20 \\
\hline $\mathbf{5}$ & 1429,11 & 168,13 & 1,81 & 1275,37 & 150,04 & 3,29 & 20 \\
\hline $\mathbf{6}$ & 1295,11 & 152,37 & 1,82 & 1151,42 & 135,46 & 3,56 & 20 \\
\hline $\mathbf{7}$ & 1323,26 & 155,68 & 1,94 & 1165,08 & 137,07 & 3,41 & 20 \\
\hline $\mathbf{8}$ & 1244,56 & 146,42 & 1,95 & 1098,15 & 129,19 & 3,42 & 20 \\
\hline $\mathbf{9}$ & 1605,60 & 188,89 & 20,70 & 1484,50 & 174,65 & 4,14 & 20 \\
\hline $\mathbf{1 0}$ & 1359,43 & 113,34 & 1,76 & 1122,56 & 118,23 & 3,54 & 20 \\
\hline
\end{tabular}

Figure 7 shows a graphical dependence of the tensile stress on the proportional deformation for the $\mathrm{C}$ group of test specimens, and Figure 8 shows a photograph of the test specimens torn in the tensile test.

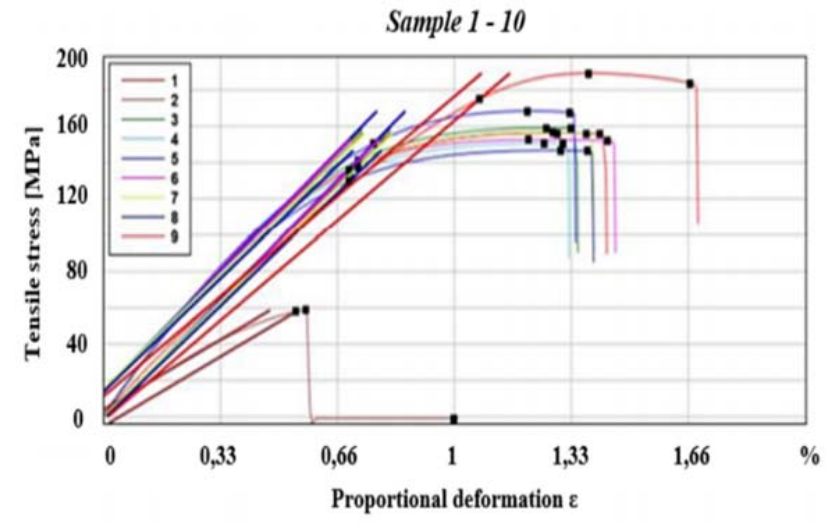

Figure 7. Graphical dependence of tensile stress on proportional deformation - specimens $D$

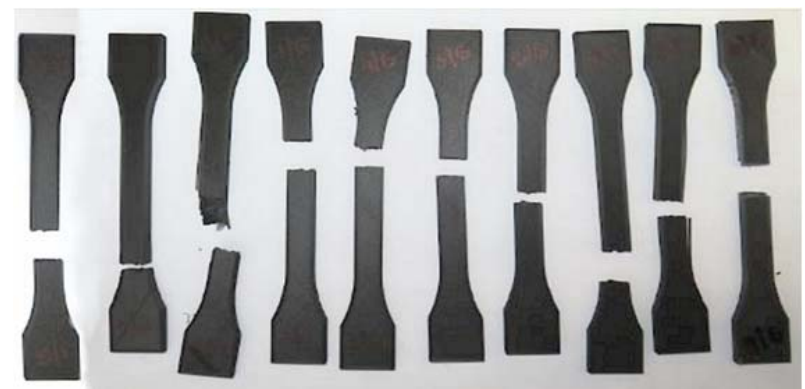

Figure 8. Torn D group test specimens

\section{Evaluation of Tensile Tests of the Materials}

The evaluation of tensile tests of individual materials was carried out by comparing the results of the average measured values of test specimens made from experimentally formulated fibers and the fibers purchased from a seller of $3 \mathrm{D}$ printing materials. A comparison of the results of the test specimens of group A and group B can be seen in Table 7 and Table 8 , respectively. 
Table 7. Achieved average result values of test specimens of group A - the clear PLA fiber (experimental material)

\begin{tabular}{|c|c|c|c|c|c|c|}
\hline \multirow{2}{*}{$\begin{array}{l}\text { Group A } \\
\text { Average } \\
\text { values }\end{array}$} & $\begin{array}{c}\text { Maximal } \\
\text { force } \\
{[\mathrm{N}]}\end{array}$ & $\begin{array}{c}\text { Tensile } \\
\text { stress at } \\
\text { max. force } \\
\text { [MPa] }\end{array}$ & $\begin{array}{l}\text { Extension } \\
\text { at max. } \\
\text { force }[\mathrm{mm}]\end{array}$ & $\begin{array}{c}\text { Force at yield } \\
\text { strength } \\
\text { (Shift 0,2\%) } \\
{[\mathrm{N}]}\end{array}$ & $\begin{array}{l}\text { Tensile stress } \\
\text { at the yield } \\
\text { strength } \\
\text { (Shift } 0,2 \% \text { ) } \\
\text { [MPa] }\end{array}$ & $\begin{array}{c}\text { Tensile } \\
\text { deformation } \\
\text { at failure } \\
{[\%]}\end{array}$ \\
\hline & 683,194 & 80,374 & 1,74 & 612,726 & 75,856 & 3,646 \\
\hline
\end{tabular}

Table 8. Achieved average result values of test specimens of group B - the clear PLA fiber (commercial material)

\begin{tabular}{|c|c|c|c|c|c|c|}
\hline \multirow{2}{*}{$\begin{array}{c}\text { Group B } \\
\text { Average }\end{array}$} & $\begin{array}{c}\text { Maximal } \\
\text { force } \\
\text { [N] }\end{array}$ & $\begin{array}{c}\text { Tensile } \\
\text { stress at } \\
\text { malues force }\end{array}$ & $\begin{array}{c}\text { Extension at } \\
\text { max. force } \\
{[\mathbf{M P a}]}\end{array}$ & $\begin{array}{c}\text { Force at yield } \\
\text { strength } \\
\text { (Shift 0,2 \%) }\end{array}$ & $\begin{array}{c}\text { Tensile stress } \\
\text { at the yield } \\
\text { strength } \\
\text { (Shift 0,2 \%) }\end{array}$ & $\begin{array}{c}\text { Tensile } \\
\text { deformation } \\
\text { at failure }\end{array}$ \\
\cline { 2 - 8 } & 1889,846 & 222,334 & 2,193 & 1713,874 & 202,947 & 4,452 \\
\hline
\end{tabular}

From the average measured values of the test specimens of group A, consisting of 10 test specimens of the PLA material (clear fiber experimental material), the average maximum force value measured was 683,194 N. Group B of test specimens consisting of 10 test specimens of the PLA material (clear fiber - commercial material) showed the average maximum force value to be $1889,846 \mathrm{~N}$. The difference between these measured values was $1206,652 \mathrm{~N}$. It follows from the values obtained that the difference between the maximum force values measured for the compared specimens of group A and group B is relatively large, but this can be explained by the fact that the group A specimens (clear fiber - experimental material) were created in pilot experiments in the extruder and ultimately met the requirements for $3 \mathrm{D}$ printing with the Creality Ender 3 printer. The printing of these test specimens revealed a number of defects which may be the cause of this significant difference in the quality of the prints. Proven defects included uneven fiber diameter, moist PLA material, and errors associated with setting the input FilaFab Pro EX350 parameters. For these reasons, the attempts at fiber production should be repeated. A comparison of the test specimen results of group $\mathrm{C}$ and group $\mathrm{D}$ can be seen in Table 9 and Table 10, respectively.

Table 9. Achieved average result values of group C test specimens - PLA material with carbon powder admixture (commercial material)

\begin{tabular}{|c|c|c|c|c|c|c|}
\hline \multirow{2}{*}{$\begin{array}{c}\text { Group C } \\
\text { Average }\end{array}$} & $\begin{array}{c}\text { Maximal } \\
\text { force } \\
\text { [N] }\end{array}$ & $\begin{array}{c}\text { Tensile } \\
\text { stress at } \\
\text { max. force } \\
\text { values }\end{array}$ & $\begin{array}{c}\text { Extension at } \\
\text { max. force } \\
{[\mathbf{M P m}]}\end{array}$ & $\begin{array}{c}\text { Force at yield } \\
\text { strength } \\
\text { (Shift 0,2 \%) }\end{array}$ & $\begin{array}{c}\text { Tensile stress } \\
\text { at the yield } \\
\text { strength } \\
\text { (Shift 0,2 \%) } \\
{[\mathbf{M P a}]}\end{array}$ & $\begin{array}{c}\text { Tensile } \\
\text { deformation } \\
\text { at failure }\end{array}$ \\
\cline { 2 - 8 } & 1365,745 & 151,41 & 2,072 & 1198,52 & 117,859 & 4,109 \\
\hline
\end{tabular}

Table 10. Achieved average result values of group D test specimens - the PLA material with carbon powder admixture (experimental material)

\begin{tabular}{|c|c|c|c|c|c|c|}
\hline Group D & $\begin{array}{c}\text { Maximal } \\
\text { force } \\
{[\mathbf{N}]}\end{array}$ & $\begin{array}{c}\text { Tensile } \\
\text { stress at } \\
\text { max. force } \\
{[\mathrm{MPa}]}\end{array}$ & $\begin{array}{c}\text { Extension at } \\
\text { max. force } \\
\text { [mm] }\end{array}$ & $\begin{array}{c}\text { Force at yield } \\
\text { strength } \\
\text { (Shift 0,2\%) } \\
{[\mathrm{N}]}\end{array}$ & $\begin{array}{l}\text { Tensile stress } \\
\text { at the yield } \\
\text { strength (Shift } \\
0,2 \% \text { ) [MPa] }\end{array}$ & $\begin{array}{c}\text { Tensile } \\
\text { deformation } \\
\text { at failure } \\
{[\%]}\end{array}$ \\
\hline $\begin{array}{c}\text { Average } \\
\text { values }\end{array}$ & 1181,524 & 141,857 & 1,779 & 1066,115 & 124,666 & 3,39 \\
\hline
\end{tabular}

From the average values measured in group C, consisting of 10 test specimens made of the PLA material with a commercially available carbon powder admixture, the average value of the maximum force was measured at 1365,745 N. Group $\mathrm{D}$ consisted of 10 test specimens made of PLA Ingeo 2003D with carbon powder admixture (experimental material), with the average value of the maximum force of $1181,524 \mathrm{~N}$. The difference between the measured values is $184,221 \mathrm{~N}$. The difference measured between these two groups of test specimens is minimal and these results can be considered very favorable. Following from the individual tests and the measured data, we can say that it is possible to produce fibers that meet the needs of $3 \mathrm{D}$ printing in the laboratory with almost identical mechanical properties as those of the massed-produced, commercially available fibers. 


\section{Conclusion}

3D printing uses a variety of technologies, materials and production methods. Since the building materials were very limited at the beginning of the birth of this technology, the printers mostly worked only with the PLA and ABS materials, which are still among the most widely used nowadays. But in a very short time, new materials have been developed and applied. Even in today's modern age, the PLA and ABS materials have not been abandoned thanks to their characteristic mechanical properties. The PLA belongs to the group of ecological materials, but it cannot be glued, painted, etc. The ABS belongs to recyclable materials processable in a number of ways, but it is not very environmentally friendly. At present, we are able to replace a material with insufficient properties with another material that meets the appropriate criteria for the application at hand. Such materials include PC, PCL, PPSU, PEI, PVA polycarbonates, waxes and other [17].

In the tests described in this paper, polylactic acid (PLA)-based fibers used for the 3D printing process by the FDM method were produced. Ingeo 2003D was chosen as the basic building material for the production of fibers, with a carbon powder admixture added thereto. The aim of the production was to create new 3D printing designated fibers with properties similar to commonly available commercial materials from manufacturers of materials for additive production. Two types of fibers were experimentally produced in the laboratory. The first type of fiber was made of clear PLA Ingeo 2003D in the form of granules. The second fiber type was made of Ingeo 2003D with carbon powder filler. Both types of fibers produced were subsequently compared with the purchased commercially available materials intended for 3D printing. The obtained tensile tests results indicate that the experimentally produced fibers may be suitable for use directly in the $3 \mathrm{D}$ printing process. Experimental production made it possible to assess the properties of the materials created with the properties of the commercially available materials, and at the same time to obtain results indicating their satisfactory condition, thanks to which it is possible to use them immediately in the $3 \mathrm{D}$ printing process.

\section{Acknowledgements}

The authors thank the Ministry of education of Slovak Republic for supporting this research by the grant VEGA no. 1/0026/19 and VEGA no. 1/0051/20.

\section{References}

[1]. Dobransky, J., Botko, F., \& Vojnova E. (2016). Monitoring of production quality for plastic component. MM Science Journal, 10, 30.

[2]. Poor, P., \& Basl, J. (2018). Czech Republic and Processes Of Industry 4.0 Implementation. Annals of DAAAM \& Proceedings, 29.

[3]. Kaščák, J., Gašpár, Š., Paško, J., Husár, J., \& Knapčíková, L. (2021). Polylactic Acid and Its Cellulose Based Composite as a Significant Tool for the Production of Optimized Models Modified for Additive Manufacturing. Sustainability, 13(3), 1256.

[4]. Panda, A., Dobransky, J., Jančík, M., Pandova, I., \& Kačalová, M. (2018). Advantages and effectiveness of the powder metallurgy in manufacturing technologies. Metalurgija, 57(4), 353-356.

[5]. Torok, J. O. Z. E. F., Kocisko, M. A. R. E. K., Teliskova, M. O. N. I. K. A., Petrus, J. A. R. O. S. L. A. V., \& Paulisin, D. U. S. A. N. (2018). Quality of 3D printed surface based on selected post processor. MM Science Journal, 6, 2346-2349.

[6]. Gibson, I., Rosen, D., Stucker, B., \& Khorasani, M. (2014). Additive manufacturing technologies (Vol. 17, p. 195). New York: Springer.

[7]. Zhang, J., \& Jung, Y. G. (Eds.). (2018). Additive manufacturing: materials, processes, quantifications and applications. Butterworth-Heinemann.

[8]. Babu, S. S., Love, L., Dehoff, R., Peter, W., Watkins, T. R., \& Pannala, S. (2015). Additive manufacturing of materials: Opportunities and challenges. MRS Bulletin, 40(12), 1154-1161.

[9]. Calì, M., Pascoletti, G., Gaeta, M., Milazzo, G., \& Ambu, R. (2020). A New Generation of BioComposite Thermoplastic Filaments for a More Sustainable Design of Parts Manufactured by FDM. Applied Sciences, 10(17), 5852.

[10]. Kuznetsov, V. E., Tavitov, A. G., Urzhumtsev, O. D., Mikhalin, M. V., \& Moiseev, A. I. (2019). Hardware factors influencing strength of parts obtained by fused filament fabrication. Polymers, 11(11), 1870.

[11]. Li, N., Huang, S., Zhang, G., Qin, R., Liu, W., Xiong, H., ... \& Blackburn, J. (2019). Progress in additive manufacturing on new materials: A review. Journal of Materials Science \& Technology, 35(2), 242-269.

[12]. Zhang, X., Li, M., Lim, J. H., Weng, Y., Tay, Y. W. D., Pham, H., \& Pham, Q. C. (2018). Large-scale 3D printing by a team of mobile robots. Automation in Construction, 95, 98-106.

[13]. Mogas-Soldevila, L., Duro-Royo, J., \& Oxman, N. (2014). Water-based robotic fabrication: large-scale additive manufacturing of functionally graded hydrogel composites via multichamber extrusion. $3 D$ Printing and Additive Manufacturing, 1(3), 141-151. 
[14]. Valíček, J., Harničárová, M., Kopal, I., Palková, Z., Kušnerová, M., Panda, A., \& Šepelák, V. (2017). Identification of upper and lower level yield strength in materials. Materials, 10(9), 982.

[15]. Straka, L., \& Hašová, S. (2016). Assessing the influence of technological parameters on the surface quality of steel MS1 after WEDM. MM Science Journal, 11, 1194-1200.
[16]. Stejskal, T., Dovica, M., Svetlik, J., \& Demec, P. (2019). Experimental assessment of the static stiffness of machine parts and structures by changing the magnitude of the hysteresis as a function of loading. Open Engineering, 9(1), 655-659.

[17]. Yuan, S., Shen, F., Chua, C. K., \& Zhou, K. (2019). Polymeric composites for powder-based additive manufacturing: Materials and applications. Progress in Polymer Science, 91, 141-168. 